\title{
Fermentative characteristics of yogurt using lactic acid bacteria isolated from Korean traditional fermented food
}

\author{
Na-Young Park, Shin-Ho Lee* \\ Department of Food Science and Technology, Daegu Catholic University, Gyeongsan 38430, Korea
}

\section{전통 발효 식품에서 분리한 유산균을 이용한 yogurt 발효특성}

\author{
박나영 - 이신호* \\ 대구가톨릭대학교 식품공학과
}

\begin{abstract}
The objective of this study was to select yogurt starter from Korean traditional fermented foods. The 2 strains (KM24, KM32) among 50 strains of isolated lactic acid bacteria selected as starter based on milk clotting ability, antimicrobial activity against various pathogens, tolerance in artificial gastric and bile juice and growth in $10 \%$ skimmed milk. The strains were identified as Lacobacillus plantarum (KM32) and Pediococcus pentosacesus (KM24) by 16S rRNA gene sequencing. Viable cell number of yogurt fermented with mixed strains (KM24 and KM32) was $9.66 \log \mathrm{CFU} / \mathrm{mL}$ after fermentation for $48 \mathrm{~h}$ and maintained $10^{9} \mathrm{CFU} / \mathrm{mL}$ during fermentation for $72 \mathrm{~h}$ at $37^{\circ} \mathrm{C}$. The $\mathrm{pH}$ and titratable acidity of mixed cultured yogurt were $4.25 \%$ and $0.83 \%$ after fermentation for 48 $h$ at $37^{\circ} \mathrm{C}$, respectively. The physico-chemical characteristics of mixed cultured yogurt after fermentation for 48 h were $38.45 \mu \mathrm{g} / \mathrm{mL}$ (polyphenol content), 48.57\% (DPPH radical scavenging activity) and $465.40 \mathrm{cp}$ (viscosity), respectively. The mixed cultured yogurt maintained $10^{9} \mathrm{CFU} / \mathrm{mL}$ of lactic acid bacteria during storage 10 days at $4^{\circ} \mathrm{C}$. The viable cell number of yogurt prepared with mixed culture(KM32+KM24) maintained higher and than that of control ( $L$. casei) during storage. These results indicated the potential use of selected strains (KM32+KM24) isolated from kimchi as a yogurt starter with strong acid tolerance and probiotics properties.
\end{abstract}

Key words : lactic acid bacteria, yogurt, kimchi, probiotic

\section{서 론}

Probiotics는 살아있는 미생물로 주로 인간의 장 건강에 유익한 영향을 미치며, 소화관의 안정성 유지, 설사 예방이 나 증상의 완화, 콜레스테롤 수치의 감소, 고혈압 완화, 면역 체계의 개선 등의 효과가 알려져 있다(1). 최근 probiotics는 전 세계적으로 기능성식품 시장의 60-70\% 차지하고 있으 며, 그 종류도 매우 다양하게 출시되고 있다(2). 유산균은 probiotics로서 설사와 변비의 치료효과, 장내 유해균의 억

*Corresponding author. E-mail : leesh@cu.ac.kr Phone : 82-53-850-3217, Fax : 82-53-850-3217

Received 8 August 2017; Revised 18 August 2017; Accepted 21 August 2017.

Copyright (c) The Korean Society of Food Preservation. All rights reserved.
제, 비타민의 생성, 혈중콜레스테롤 저하능, 항암효과, 인체 의 면역력 증강 등 다양한 기능성이 보고되고 있다(3). 대부 분 산업적으로 이용되고 있는 probiotics는 인간의 장관이나 유제품 등에서 분리한 동물 유래 유산균이었으나, 최근 Pediococcus, Leuconostoc 속 등 식물유래 유산균이 probiotic 기능이 있다고 밝혀지고 있다(4). 요구르트는 발 효 중 유산균이 생성한 산에 의해 우유 단백질인 casein의 안전성이 파괴되어 겔(curd)이 형성되며(5), 요구르트제조 에 사용되는 probiotic 유산균은 $\mathrm{pH} 4.5$ 이하의 산성조건에 서 내성이 있어야 하나(6), 인간의 장에서 분리한 유산균은 산성조건에 매우 민감하므로(7) 현재 발효유 제품 제조에 사용되는 유산균은 특히 내산성이 강한 균주를 사용하고 있으며, 위산과 담즙에 내성이 있어야 한다(8).

김치는 원재료들이 갖는 생리활성과 발효미생물인 유산 균의 probiotics 기능을 동시에 갖는 채소 발효식품(9)으로 
발효는 초기 원재료에 존재하는 여러 종의 미생물에 의해 시작되나 발효가 점차 진행됨에 따라 산도가 증가하여 유산 균이 대부분 차지하게 된다. 김치는 $\mathrm{pH} 4.2$ 이하, 적정산도 $0.6 \%$ 상태에서 가장 풍미가 좋으며(10), 젖산균수는 $10^{7}-10^{9}$ $\mathrm{CFU} / \mathrm{g}(11)$ 을 유지하고 있다. 김치 유산균은 김치의 $\mathrm{pH} 4.2$ 이하 에서도 생육이 가능하므로 내산성이 있어 우유 응고능 이 있는 김치 발효 유산균은 요구르트 제조에 사용이 가능 할 것으로 판단된다. 최근 식혜, 막걸리, 김치 등 식물성 재료를 이용한 발효식품과 관련된 유산균의 영양학적, 약 리학적 장점들이 알려지면서 항균활성 및 기능적 특성에 관한 연구(12-13)가 보고되고 있다.

본 연구는 유산발효를 하는 전통식품에서 요구르트 제조 에 활용이 가능한 산내성이 있는 유산균을 분리하여 probiotics 기능을 검증하고 이를 이용한 요구르트 제조 중 발효특성 및 품질 특성을 검토하였다.

\section{재료 및 방법}

\section{균주의 분리 및 선발}

균주의 분리원은 대구 경북지역에서 수집한 김치, 식혜, 막걸리, 물김치 등 전통 발효식품을 사용하였으며, 각 샘플 을 직접 또는 적정 희석하여 $0.02 \%$ sodium azide가 포함된 MRS Agar(Difco Co. Detroit, MI, USA)에 도말하고, $37^{\circ} \mathrm{C}$ 에 서 24시간 배양 후 나타난 특징적인 colony를 취하여 순수 분리한 50 균주를 $10 \%$ 탈지분유에 접종하여 $37^{\circ} \mathrm{C}$ 에서 48-72시간동안 배양한 후 응고현상을 보인 16균주를 선발 하였다. 선발 균주는 MRS 사면배지에 접종하여 24시간 배양한 후 $4^{\circ} \mathrm{C}$ 에 보관하면서 사용하였다.

\section{항균활성 측정}

선발된 균주에 대한 항균활성은 Listeria monocytogenus ATCC19115, Staphylococcus aureus ATCC2937, Bacillus cereus ATCC14581, Escherichia coli ATCC11775, Salmonella entritidis KCTC12400, Vibrio vulnificus ATCC 17802에 대 해 paper disc method로 생육 억제환 생성 유무를 비교 측정 하였다.

\section{인공 위액 및 담즙산에 대한 내성 측정}

Kobayashi 등(14)의 방법을 변형하여 내산성이 강한 균주 를 선발하기 위하여 $1 \mathrm{~N} \mathrm{HCl}$ 을 사용하여 $\mathrm{pH} 1.5$ 로 조정한 nutrient broth(Difco Co., Detroit, MI, USA)에 pepsin $1 \%$ 를 첨가한 인공 위액을 사용하였다. 선발 균주를 상기 인공위 액에 접종하여 $37^{\circ} \mathrm{C}$ 에서 3 시간 배양 후 $1 \mathrm{~mL}$ 을 취하여 $0.1 \%$ pepton 용액으로 적정 희석하여 MRS agar(Difco Co.) 에 접종, $37^{\circ} \mathrm{C}$ 에서 24 시간 배양 후 나타난 colony수를 계측 하였다. 분리균주의 인공담즙 액에 대한 내성은 Lee 등(15)
의 방법으로 MRS broth에 pancreatin(Kanto Chemical, Tokyo, Japan) $1 \%$ 를 첨가한 후 $\mathrm{pH} 8.3$ 으로 조정하여 멸균시 킨 후, 멸균된 $10 \%$ Oxgall(Difco Co.) 용액 $1 \%$ 를 첨가한 배지를 사용하였으며, 인공위액에서 3 시간 배양 후 원심분 리하여 상등액을 제거한 균체에 인공담즙 액을 첨가하여 $37^{\circ} \mathrm{C}$ 에서 24 시간 배양한 후 생균수를 측정 하였다.

\section{환원 탈지유에서의 성장 검사}

분리 유산균 중 항균활성, 내산성과 내담즙성이 있는 균 주를 선발하여 24시간 배양한 배양액을 각각 고형분 함량 $10 \%$ 멸균 환원탈지유에 $3 \%(\mathrm{v} / \mathrm{v})$ 접종하여 4 일간 배양하면 서 1 일 간격으로 $\mathrm{pH}$, 산도, 생균수를 측정비교 하였다.

\section{균주의 동정}

최종 선별된 균주를 Gram 염색, catalase test, API $50 \mathrm{CHL}$ kit(BioMerieux Co., Marcy L'Etoile, France)간이 동정한 후 Zhang 등(16)의 27F(5'-AGAGTTTGA TCCTGGCTCAG-3') 와 1429R(5'-GGTTACCTTGTTACGACTT-3') primer를 사 용하여 RNA를 증폭 후 $16 \mathrm{~S}$ rRNA 염기서열 분석을 통해 (Solgent Co., Daejeon, Korea) 확인하였다.

\section{선발균주를 이용한 요구르트의 제조}

내산성, 내담즙성, 항균활성, 환원탈지유에서 성장능 등 이 우수한 2 균주를 선발, 단독 및 혼합 starter로 $10 \%$ 멸균 환원탈지유에 각각 $3 \%(\mathrm{v} / \mathrm{v})$ 접종한 후 4 일간 배양하였으며, 대조구로 발효가 비교적 완만하게 진행되는 요구르트 제조 에 starter로 사용되는 Lactobacillus casei(CHR, Hansens Lab., Horsholm, Denmark)를 사용하였다.

\section{$\mathrm{pH}$ 및 적정산도 측정}

발효 중 24시간 간격으로 각 시료 $10 \mathrm{~mL}$ 를 취하여 $\mathrm{pH}$ 는 $\mathrm{pH}$ meter(Corning, $\mathrm{pH}$ meter 445, Medifield, MA, USA)로, 적정산도는 동일량의 시료에 $0.1 \mathrm{~N} \mathrm{NaOH}$ (Factor=1.001)를 $\mathrm{pH}$ 가 8.3이 될 때까지 적정한 $\mathrm{NaOH}$ 용액의 소비량을 젖산 으로 환산하였다.

\section{유산균수 측정}

발효 중 24시간 간격으로 시료 $1 \mathrm{~mL}$ 를 무균적으로 취한 후 $0.1 \%$ pepton수로 적정 희석한 후 MRS agar(Difco.)에 접종하여 $37^{\circ} \mathrm{C}$ 에서 24 시간 배양 후 나타난 colony수를 $\mathrm{mL}$ 당 colony forming unit(CFU)로 나타내었다.

\section{점도 측정}

점도는 발효가 완료된 요구르트 시료 $10 \mathrm{~g}$ 을 각각 취하여 Brookfield viscometer(LVDV- $\Pi$, brookfield Engineering Lab Inc., Middleboro, MA, USA)의 18번 spindle을 사용, $1.5 \mathrm{rpm}$ 에서 5 분경과 후 1 분 간격으로 6 회 측정하여 평균값 


\section{으로 나타내었다.}

\section{총 폴리페놀 함량 측정}

Folin-Denis 법(17)에 따라 발효가 완료된 시료 $1 \mathrm{~mL}$ 에 0.2 N Folin-ciocalteu's phenol reagent(Sigma-Aldrich Co., St. Louis, MO, USA) $1 \mathrm{~mL}$ 를 가하여 실온에서 3분간 반응시 킨 후, $7.5 \% \mathrm{Na}_{2} \mathrm{CO}_{3} 1 \mathrm{~mL}$ 을 가하여 암소에서 1 시간 동안 방치한 후 $765 \mathrm{~nm}$ 에서 흡광도를 측정하였다. 총 폴리페놀 함량은 gallic acid를 표준물질로 한 표준곡선에 의하여 산출 하였다.

\section{DPPH radical 소거능 측정}

Blois의 방법(18)을 변형하여 발효가 완료된 요구르트와 $95 \%$ ethanol를 $1: 1$ 로 비율로 혼합, 24 시간 추출한 후 $4{ }^{\circ} \mathrm{C}$, $3,500 \mathrm{rpm}$ 에서 10 분간 원심분리(Supra $21 \mathrm{k}$, Hanil science industrial Co., Ltd., Incheon, Korea)한 후 얻은 상등액을 여과지(Whatman No. 2, Maidstone, England)로 여과시켜 사용하였다. 시료 $0.4 \mathrm{~mL}$ 에 $0.4 \mathrm{mM} \mathrm{DPPH}$ 에탄올 용액 $0.8 \mathrm{~mL}$ 를 가하여 진탕 혼합하고 상온에서 10 분간 방치 후, $525 \mathrm{~nm}$ 에서 흡광도를 측정하였으며, 계산식, DPPH radical scavenging activity $(\%)=100-[(\mathrm{OD}$ of sample/OD of control) $\times 100$ ]에 의하여 활성을 산출하였다.

\section{요구르트의 저장성}

$10 \%$ 멸균 환원탈지유에 분리균주를 단독 및 혼합 접종하 여 48 시간 배양한 후 $4^{\circ} \mathrm{C}$ 에 10 일간 저장하면서 저장 중 $\mathrm{pH}$, 산도, 생균수의 변화를 비교하였다.

\section{통계처리}

모든 실험은 3회 반복으로 행하였으며, 유의성 검증은 SPSS(Statistical Package for Social Sciences, SPSS Inc., Chicago, IL, USA) software package(version 19.0)를 이용, $\mathrm{p}<0.05$ 수준으로 Duncan's multiple range test에 의하여 검증 하였다.

\section{결과 및 고찰}

\section{분리균주의 항균활성과 인공위액 및 인공 담즙액에 대한 내성}

분리한 50 균주의 유산균중 커드형성 능력이 있는 16 균주 를 선발하여 그람 양성균인 L. monocytogenes, S. aureus, B. cereus와 그람 음성균인 E. coli, S. entritidis, V. vulnificusicus 에 대한 항균활성을 측정한 결과(Table 1) KM32 균주가 가장 우수한 항균활성을 나타내었다. 공시 균주 중 항균 spectrum이 비교적 넓은 9균주를 선발하여 다음 실험에 사 용하였다.
Table 1. Antimicrobial activity of isolated strains against various pathogens

\begin{tabular}{ccccccccccc}
\hline & $\mathrm{A}^{\mathrm{l}}$ & $\mathrm{B}$ & $\mathrm{C}$ & $\mathrm{D}$ & $\mathrm{E}$ & $\mathrm{F}$ & $\mathrm{G}$ & $\mathrm{H}$ & shape & orgin \\
\hline $\mathrm{KM} 2$ & $+{ }^{2)}$ & + & + & + & + & - & + & + & cocci & kimchi \\
KM9 & + & + & + & + & + & - & + & + & cocci & kimchi \\
KM12 & - & - & - & + & - & - & - & - & rod & kimchi \\
KM24 & + & + & + & + & + & - & + & + & cocci & kimchi \\
KM29 & - & - & + & + & + & - & - & - & rod & kimchi \\
KM32 & + & + & + & + & + & + & + & + & rod & kimchi \\
KM38 & - & - & - & - & + & - & - & - & cocci & kimchi \\
KM43 & - & + & + & + & + & + & + & - & rod & kimchi \\
KM45 & - & - & - & - & - & - & + & - & rod & mackuli \\
KM52 & - & - & - & + & - & - & + & + & rod & sikhae \\
KM57 & - & - & - & - & - & - & - & - & cocci & sikhae \\
KM63 & - & + & + & + & - & - & + & + & rod & kimchi \\
KM69 & - & - & - & - & - & - & - & - & rod & sikhae \\
KM72 & - & + & + & + & + & - & + & + & rod & mulkimchi \\
KM75 & - & - & - & - & - & - & - & - & rod & sikhae \\
KM82 & - & - & + & + & + & - & + & + & rod & kimchi \\
\hline
\end{tabular}

${ }^{1)} A$ Bacillus cereus, B, Listeria monocytogenes, C, Staphylococcus aureus, D, E. coli, E, almonella Typhymurium, F, Vibrio vulnificus, G, Salmonella entertidis.

${ }^{2)}+$, positive; -, negative.

구강을 통해 섭취되는 probiotics는 강산성의 위산과 담즙 산에서 살아남아 췌장과 십이지장을 통과하여 최종 목적 부위인 장에 도달하여야 정장의 효과를 발휘하게 된다(19). 항균활성이 우수한 9균주의 인공위액과 인공 담즙액에서 내성은 양호하였으며(Table 2), KM32는 본 실험에 사용한 $\mathrm{pH}$ 를 1.5 로 조정한 인공 위액에서 $\log$ reduction이 1.14 를 나타내었고, 인공 담즙액에서는 생균수가 증가하는 경향

Table 2. Viable cell of selected lactic acid bacteria after treatment in artificial gastric juice and bile acid at $37^{\circ} \mathrm{C}$

(log No. CFU/mL)

\begin{tabular}{|c|c|c|c|c|}
\hline \multirow{2}{*}{ Strains ${ }^{1)}$} & \multicolumn{2}{|c|}{ Acid tolerance } & \multicolumn{2}{|c|}{ Bile Tolerance } \\
\hline & Beforer $^{2)}$ & After $^{3)}$ & Before & After \\
\hline KM2 & $8.22 \pm 0.09^{4 /(5)}$ & $7.03 \pm 0.16^{b}(1.19)^{3}$ & $7.66 \pm 0.05^{\mathrm{ab}}$ & $7.53 \pm 0.13^{\mathrm{c}}(0.13)$ \\
\hline KM9 & $8.39 \pm 0.12^{\mathrm{bc}}$ & $4.07 \pm 0.22^{\mathrm{e}}(4.32)$ & $7.46 \pm 0.02^{\mathrm{de}}$ & $7.71 \pm .09^{b c}(-0.25)$ \\
\hline KM24 & $8.45 \pm 0.12^{\mathrm{b}}$ & $6.44 \pm 0.08^{\mathrm{d}}(2.01)$ & $7.44 \pm 0.06^{\text {de }}$ & $7.93 \pm 0.03^{\mathrm{a}}(-0.49)$ \\
\hline KM29 & $8.84 \pm 0.04^{\mathrm{a}}$ & $6.81 \pm 0.04^{\mathrm{c}}(2.03)$ & $7.62 \pm 0.06^{\mathrm{bcc}}$ & $7.66 \pm 0.12^{\mathrm{c}}(-0.04)$ \\
\hline KM32 & $8.79 \pm 0.07^{\mathrm{a}}$ & $7.65 \pm 0.06^{\mathrm{a}}(1.14)$ & $7.54 \pm 0.08^{\text {bed }}$ & $8.32 \pm 0.04^{\mathrm{a}}(-0.78)$ \\
\hline KM43 & $8.48 \pm 0.17^{b}$ & $7.21 \pm 0.11^{\mathrm{b}}(1.28)$ & $7.50 \pm 0.12^{\text {de }}$ & $5.86 \pm 0.07^{\mathrm{e}}(1.64)$ \\
\hline KM63 & $8.32 \pm 0.08^{\mathrm{bc}}$ & $6.72 \pm 0.07^{\mathrm{c}}(1.60)$ & $7.47 \pm 0.05^{\text {de }}$ & $6.73 \pm 0.05^{\mathrm{d}}(0.74)$ \\
\hline KM72 & $8.87 \pm 0.04^{\mathrm{a}}$ & $7.73 \pm 0.04^{\mathrm{a}}(1.15)$ & $7.40 \pm 0.10^{e}$ & $6.70 \pm 0.20^{\mathrm{d}}(0.71)$ \\
\hline KM82 & $8.92 \pm 0.04^{\mathrm{a}}$ & $7.14 \pm 0.06^{b}(1.79)$ & $7.68 \pm 0.06^{\mathrm{a}}$ & $6.51 \pm 0.31^{\mathrm{d}}(1.17)$ \\
\hline
\end{tabular}

${ }^{1)}$ lactic strains isolated from korean traditional fermented foods.

${ }^{2)}$ Survival cell in artificial gastric juice $(\mathrm{pH}=1.5)$ for $3 \mathrm{~h}$ at $37^{\circ} \mathrm{C}$.

${ }^{3)}$ Survival cell in artificial bile acid for $24 \mathrm{~h}$ at $37^{\circ} \mathrm{C}$ treated with artificial gastric juice for $3 \mathrm{~h}$ at $37^{\circ} \mathrm{C}$

${ }^{4} \log$ reduction. Value are means \pm SD of triplicate determinations.

${ }^{5)+0}$ Means within each column with no common superscripts are significantly different $(\mathrm{p}<0.05)$. 
(log reduction, -0.78)을 나타내어 소화기관을 통과하는 동 안 우수한 생존율을 나타낼 수 있을 것으로 판단되었다. 내산성이 매우 강하고 담즙액에 대한 내성이 우수한 KM2, $\mathrm{KM} 24, \mathrm{KM} 32$ 그리고 KM 72 균주를 선발하여 환원탈지유 에서 배양특성을 비교하였다.

\section{선발균주의 환원탈지유에서 배양특성과 동정}

요구르트 starter로 이용 가능성을 검증하기 위하여 $\mathrm{KM} 2$, $\mathrm{KM} 24, \mathrm{KM} 32$ 와 KM72균주의 환원 탈지유에서 배양 중 생 균수, $\mathrm{pH}$, 산도의 변화를 Table 3에 나타내었다. KM24 균주 가 가장 높은 생균수를 나타내어 배양 4 일 동안 $10^{9} \mathrm{CFU} / \mathrm{mL}$ 을 유지하였다. $\mathrm{pH}$ 의 변화는 $\mathrm{KM} 24$ 균주의 경우 배양 초기 부터 감소하여 배양 2 일째 $\mathrm{pH} 4.60$ 으로 낮아져 배양 3 일 이후 4.10 이하를 나타내었다. 산도의 변화도 $\mathrm{pH}$ 와 유사한 경향을 나타내었으며 $\mathrm{KM} 24$ 의 경우 배양 2 일째 $0.87 \%$, 배 양 3 일 이후 $1.04 \%$ 를 유지하였다. 요구르트내 유산균수는 $10^{7}-10^{8} \mathrm{CFU} / \mathrm{mL}$ 이상 $(20), \mathrm{pH}$ 는 4.1-4.2(21), 적성산도의 범위는 0.95-1.20\%로 제시한 Rasic과 Kurmann(5) 등의 결과 와 비교하면 공시균주는 환원탈지유에서 성장은 양호하나 완만하게 산을 생성하여 요구르트 제조를 위해 배양기간이 2일 이상 필요한 것으로 판단되었다. KM24(구균) 균주만 단독으로 요구르트 제조용 starter로 사용이 가능할 것으로 사료되었으나, 내산성과 담즙액 내성 그리고 환원탈지유에 서의 양호한 성장을 나타낸 KM32(간균)가 KM24와 발효 중 구균인 $S$, thermophilus 와 간균인 L. bulgaricus와 같은 상호작용이 가능할 것으로 판단되어 두 균주를 선발하여

Table 3. Changes of viable cell, $\mathrm{pH}$ and titratable acidity in $10 \%$ skim milk inoculated with isolated lactic strains during fermentation for 4 days at $37^{\circ} \mathrm{C}$

\begin{tabular}{|c|c|c|c|c|c|c|}
\hline & & \multicolumn{5}{|c|}{ Fermentation time (day) } \\
\hline & & 0 & 1 & 2 & 3 & 4 \\
\hline \multirow{4}{*}{$\begin{array}{c}\text { Viable } \\
\text { cell } \\
\text { (log No. } \\
\text { CFU } / \mathrm{mL})\end{array}$} & KM2 & $7.18 \pm 0.13^{1 / \mathrm{a} 2)}$ & $9.03 \pm 0.04^{b}$ & $9.61 \pm 0.20^{\mathrm{ab}}$ & $8.98 \pm 0.03^{b}$ & $8.60 \pm 0.07^{\mathrm{c}}$ \\
\hline & $\mathrm{KM} 24$ & $7.57 \pm 0.54^{\mathrm{a}}$ & $8.74 \pm 0.07^{c}$ & $9.56 \pm 0.22^{\mathrm{ab}}$ & $9.37 \pm 0.23^{\mathrm{a}}$ & $9.03 \pm 0.03^{\mathrm{a}}$ \\
\hline & KM72 & $7.30 \pm 0.07^{\mathrm{a}}$ & $7.44 \pm 0.06^{d}$ & $9.35 \pm 0.22^{\mathrm{b}}$ & $8.81 \pm 0.02^{b}$ & $8.61 \pm 0.03^{\mathrm{c}}$ \\
\hline & KM32 & $7.07 \pm 0.09^{\mathrm{a}}$ & $9.19 \pm 0.12^{\mathrm{a}}$ & $9.80 \pm 0.06^{\mathrm{a}}$ & $8.99 \pm 0.02^{\mathrm{b}}$ & $8.77 \pm 0.03^{b}$ \\
\hline \multirow{4}{*}{$\mathrm{pH}$} & KM2 & $6.50 \pm 0.02^{\mathrm{b}}$ & $5.34 \pm 0.03^{\mathrm{b}}$ & $4.96 \pm 0.06^{\mathrm{b}}$ & $4.64 \pm 0.02^{b}$ & $4.72 \pm 0.04^{\mathrm{a}}$ \\
\hline & KM24 & $6.41 \pm 0.02^{\mathrm{c}}$ & $5.03 \pm 0.08^{\mathrm{c}}$ & $4.60 \pm 0.05^{\mathrm{c}}$ & $4.12 \pm 0.02^{\mathrm{c}}$ & $4.10 \pm 0.02^{\mathrm{d}}$ \\
\hline & KM72 & $6.49 \pm 0.01^{\mathrm{b}}$ & $6.10 \pm 0.02^{\mathrm{a}}$ & $5.46 \pm 0.05^{\mathrm{a}}$ & $4.85 \pm 0.02^{\mathrm{a}}$ & $4.63 \pm 0.03^{b}$ \\
\hline & KM32 & $6.54 \pm 0.03^{\mathrm{a}}$ & $5.39 \pm 0.01^{\mathrm{b}}$ & $4.88 \pm 0.03^{\mathrm{b}}$ & $4.64 \pm 0.04^{b}$ & $4.50 \pm 0.03^{\mathrm{c}}$ \\
\hline \multirow{4}{*}{$\begin{array}{l}\text { Titratable } \\
\text { acidity } \\
(\%)\end{array}$} & KM2 & $0.21 \pm 0.01^{\mathrm{b}}$ & $0.63 \pm 0.01^{\mathrm{ab}}$ & $0.73 \pm 0.01^{\mathrm{c}}$ & $0.88 \pm 0.01^{\mathrm{ab}}$ & $0.91 \pm 0.03^{\mathrm{a}}$ \\
\hline & KM24 & $0.22 \pm 0.01^{\mathrm{ab}}$ & $0.79 \pm 0.01^{\mathrm{a}}$ & $0.87 \pm 0.01^{\mathrm{a}}$ & $1.04 \pm 0.02^{\mathrm{a}}$ & $1.02 \pm 0.02^{b}$ \\
\hline & KM72 & $0.22 \pm 0.01^{\mathrm{ab}}$ & $0.43 \pm 0.01^{b}$ & $0.70 \pm 0.01^{\mathrm{d}}$ & $0.76 \pm 0.04^{b}$ & $0.80 \pm 0.01^{\mathrm{ab}}$ \\
\hline & KM32 & $0.23 \pm 0.01^{\mathrm{a}}$ & $0.64 \pm 0.01^{\mathrm{ab}}$ & $0.77 \pm 0.01^{b}$ & $0.86 \pm 0.01^{\mathrm{ab}}$ & $0.81 \pm 0.01^{\mathrm{ab}}$ \\
\hline
\end{tabular}

단독 및 혼합배양 효과를 검토하였다.

선발된 2 균주를 $16 \mathrm{~S} \mathrm{rRNA}$ 염기서열 분석을 이용하여 동정 결과(Table 4), KM24는 gram positive, cocci, catalase negative였으며, Pediococcus pentosaceus로 동정되었다. $\mathrm{KM} 32$ 는 gram positive, rod, catalase negative로 Lactobacillus plantarum로 동정되었다.

Table 4. Identification of selected lactic acid bacteria by 16S rRNA gene sequencing

\begin{tabular}{|c|c|c|c|c|c|}
\hline Strains & Source & $\begin{array}{c}\text { Gram } \\
\text { staining }\end{array}$ & Shape & $\begin{array}{c}\text { Catalase } \\
\text { test }\end{array}$ & Identification (Similarity, \%) \\
\hline KM24 & Kimchi & + & cocci & - & Pediococcus pentosaceus (99\%) \\
\hline KM32 & Kimchi & + & rod & - & Lactobacillus plantarum $(100 \%)$ \\
\hline
\end{tabular}

\section{단독 및 혼합균주의 요구르트 발효특성}

비교적 산 생성이 완만한 요구르트 starter로 사용되는 Lactobacillus casei(대조구), 분리균주인 P. pentosaseus $\mathrm{KM} 32$ 와 L. plantarum $\mathrm{KM} 24$ 균주를 단독(단독접종구) 및 혼합접종(혼합 접종구)하여 요구르트 제조 중 발효특성을 비교하였다(Table 5). 유산균수는 모든 처리구에서 배양 24 시간째 $10^{8} \mathrm{CFU} / \mathrm{mL}$ 이상 이었으며 배양 72 시간까지 동일한 수준을 유지하였다. 혼합 접종구에서 배양 48시간과 배양 72시간째 각각 $9.66 \log \mathrm{CFU} / \mathrm{mL}$ 과 $9.58 \log \mathrm{CFU} / \mathrm{mL}$ 을 나타 내어 대조구보다 양호하였다. 이 결과는 김치에서 분리한

Table 5. Changes in vialbe cell, $\mathrm{pH}$ and titratable acidity of yogurt fermented with single and mixed starter during fermentation for $72 \mathrm{~h}$ at $37^{\circ} \mathrm{C}$

\begin{tabular}{|c|c|c|c|c|c|}
\hline & \multirow{2}{*}{ Samples ${ }^{1)}$} & \multicolumn{4}{|c|}{ Fermentation time (h) } \\
\hline & & 0 & 24 & 48 & 72 \\
\hline \multirow{4}{*}{$\begin{array}{c}\text { Viable Cell } \\
\text { (log No. } \\
\text { CFU/mL) }\end{array}$} & & $7.10 \pm 0.07^{2 / b 3)}$ & $8.94 \pm 0.04^{b}$ & $8.70 \pm 0.09^{c}$ & $8.59 \pm 0.03^{\mathrm{d}}$ \\
\hline & KM24 & $7.16 \pm 0.08^{b}$ & $9.19 \pm 0.09^{\mathrm{a}}$ & $8.99 \pm 0.06^{b}$ & $9.03 \pm 0.04^{b}$ \\
\hline & KM32+KM24 & $7.24 \pm 0.17^{\mathrm{ab}}$ & $8.86 \pm 0.06^{b}$ & $9.66 \pm 0.09^{\mathrm{a}}$ & $9.58 \pm 0.07^{\mathrm{a}}$ \\
\hline & Control & $7.66 \pm 0.07^{\mathrm{a}}$ & $9.16 \pm 0.03^{\mathrm{a}}$ & $9.09 \pm 0.06^{b}$ & $8.93 \pm 0.06^{\mathrm{C}}$ \\
\hline \multirow{4}{*}{$\mathrm{pH}$} & KM32 & $6.55 \pm 0.03^{\mathrm{a}}$ & $5.44 \pm 0.01^{\mathrm{a}}$ & $4.74 \pm 0.02^{\mathrm{a}}$ & $4.50 \pm 0.01^{\mathrm{a}}$ \\
\hline & KM24 & $6.54 \pm 0.01^{\mathrm{a}}$ & $4.97 \pm 0.01^{\mathrm{d}}$ & $4.31 \pm 0.01^{b}$ & $4.09 \pm 0.01^{b}$ \\
\hline & KM32+KM24 & $6.48 \pm 0.02^{b}$ & $5.04 \pm 0.01^{\mathrm{c}}$ & $4.25 \pm 0.01^{\mathrm{c}}$ & $4.04 \pm 0.01^{\mathrm{c}}$ \\
\hline & Control & $6.39 \pm 0.01^{\mathrm{c}}$ & $5.17 \pm 0.01^{\mathrm{b}}$ & $3.77 \pm 0.01^{\mathrm{d}}$ & $3.46 \pm 0.01^{\mathrm{d}}$ \\
\hline \multirow{4}{*}{$\begin{array}{l}\text { Titratable } \\
\text { acidity } \\
(\%)\end{array}$} & KM32 & $0.20 \pm 0.01^{b}$ & $0.43 \pm 0.01^{\mathrm{d}}$ & $0.68 \pm 0.01^{\mathrm{d}}$ & $0.76 \pm 0.01^{\mathrm{d}}$ \\
\hline & KM24 & $0.20 \pm 0.01^{b}$ & $0.76 \pm 0.01^{\mathrm{a}}$ & $0.85 \pm 0.01^{\mathrm{b}}$ & $0.88 \pm 0.01^{\mathrm{c}}$ \\
\hline & KM32+KM24 & $0.20 \pm 0.01^{\mathrm{b}}$ & $0.71 \pm 0.01^{\mathrm{c}}$ & $0.83 \pm 0.01^{\mathrm{c}}$ & $0.99 \pm 0.01^{b}$ \\
\hline & Control & $0.22 \pm 0.01^{\mathrm{a}}$ & $0.76 \pm 0.01^{b}$ & $0.99 \pm 0.01^{\mathrm{a}}$ & $1.24 \pm 0.01^{\mathrm{a}}$ \\
\hline
\end{tabular}

${ }^{11}$ Control, Lactobacillus. casei, KM32, Pediococcus. pentosaseus, KM24, Lactobacillus. plantarum, KM32+KM23, $P$. pentosaceus $+L$. plantarum

${ }^{2)}$ Value are means $\pm S D$ of triplicate determinations.

${ }^{3)-d}$ Means within e6ach column with no common superscripts are significantly different $(\mathrm{p}<0.05)$. 
L. plantarum을 환원탈지유에서 24시간 배양 후 108 $\mathrm{CFU} / \mathrm{mL}$ 이었다는 Jeong 등(22)의 결과 보다 양호하였다. 분리 균주를 복합으로 사용할 경우 비교적 유산균을 많이 함유하는 요구르트 제조가 가능할 것으로 판단되었다. $\mathrm{pH}$ 변화는 배양 48시간째 대조구(3.77), KM24 단독 접종구와 혼합 접종구에서 각각 4.31 과 4.25 이었다. 산도의 변화는 $\mathrm{pH}$ 변화와 유사하여 배양 48 시간 후 $\mathrm{KM} 32(0.68 \%), \mathrm{KM} 24$ $(0.85 \%)$, 혼합 접종구 $(0.83 \%)$, 대조구 $(0.99 \%)$ 이었으며, $\mathrm{KM} 32$ 단독 접종구를 제외하고 각 처리구 공히 배양 72 시간 후 0.88-1.24\%의 범위를 나타내었다. 혼합 접종구는 대조구 에 비해 산생성은 완만하였으나 유산균수는 많았다. 이러 한 결과를 김치에서 선발한 유산균을 이용한 요구르트 제조 중 배양 24 시간 이후 $\mathrm{pH}$ 는 4.3 이었다는 결과(23)와 탈지유 로 제조한 요구르트의 $\mathrm{pH}$ 범위는 4.01-4.27, 산도는 0.82-1.15\%(24), mild 요구르트와 acid 요구르트의 적정산도 범위는 각각 0.85- 0.95\%와 0.951- $1.20 \%$ (5)라는 결과와 비 교해 볼 때 $\mathrm{KM} 32$ 와 $\mathrm{KM} 24$ 혼합균주는 mild요구르트 제조 에 적합하다고 판단되며, 산 생성이 완만하여 배양시간이 48 시간 이상 필요할 것으로 사료되었다.

총 폴리페놀함량, DPPH 라디칼 소거능, viscosity 비교 요구르트의 항산화 활성과 점도의 비교는 Table 6에서 보는 바와 같이 $\mathrm{KM} 24$ 단독 접종구가 총 폴리페놀함량 $(41.56 \mu \mathrm{g} / \mathrm{mL})$ 이 가장 높았으며, $\mathrm{DPPH}$ 라디칼 소거능도 $\mathrm{KM} 24$ 접종구가 가장 높은 $52.54 \%$ 로 혼합 접종구(48.57\%) 와 대조구(48.22\%)에 비해 항산화 활성이 가장 우수하였다.

Table 6. Comparision of antioxidative activity and viscosity of yogurt fermented single and mixed starter

\begin{tabular}{ccccc}
\hline & \multicolumn{4}{c}{ Samples $^{\mathrm{l})}$} \\
\cline { 2 - 5 } & KM32 & KM24 & KM32+KM24 & Control \\
\hline $\begin{array}{c}\text { Total polyphenol } \\
(\mu \mathrm{g} / \mathrm{mL})\end{array}$ & $33.15 \pm 0.09^{2) \mathrm{d} 3)}$ & $41.56 \pm 0.05^{\mathrm{a}}$ & $38.45 \pm 0.30^{\mathrm{c}}$ & $38.86 \pm 0.07^{\mathrm{b}}$ \\
$\begin{array}{c}\text { DPPH radical } \\
\text { scavenging activity } \\
(\%)\end{array}$ & $44.42 \pm 0.13^{\mathrm{c}}$ & $52.54 \pm 0.15^{\mathrm{a}}$ & $48.57 \pm 0.30^{\mathrm{b}}$ & $48.22 \pm 0.11^{\mathrm{b}}$ \\
& & & & \\
Viscosity (cp) & $135.20 \pm 1.49^{\mathrm{d}}$ & $675.30 \pm 1.45^{\mathrm{a}}$ & $465.40 \pm 2.30^{\mathrm{c}}$ & $548.80 \pm 2.20^{\mathrm{b}}$
\end{tabular}

${ }^{1)}$ Control, Lactobacillus. casei, KM32, Pediococcus. pentosaseus, KM24, Lactobacillus. plantarum, KM32+KM23, P. pentosaceus $+L$. plantarum.

${ }^{2)}$ Value are means $\pm \mathrm{SD}$ of triplicate determinations except viscosity ( $\mathrm{n}=6$ )

${ }^{3) \text { ad }}$ Means within each row with no common superscripts are significantly different $(\mathrm{p}<0.05)$.

요구르트 제조용 starter YC-380을 이용한 요구르트의 $\mathrm{DPPH}$ 라디칼 소거능이 $24.5 \%$ 였다는 보고(24)와 비교할 때 혼합 접종구의 항산화활성은 비교적 양호한 것으로 판단 된다. 요구르트의 점도는 소비자의 기호성에 영향을 미치 는 주요 요인으로 $\mathrm{KM} 24$ 접종구의 점도 $(675 \mathrm{cp})$ 가 가장 높았으며, 혼합 접종한 경우 $465 \mathrm{cp}$ 로 감소하였다. 요구르
트의 점도는 요구르트 혼합액의 총 고형분 함량과 단백질 가수분해정도, starter의 산과 slime 생성능력에 의해 영향을 받는다(5). 요구르트의 지방함량이 감소할수록 강도가 약 한 겔을 형성하게 되어 물성학적 특성이나 조직특성, 맛, 풍미 등에 바람직하지 못한 영향을 미치게 된다(25). 공시 요구르트의 낮은 점도는 본 연구에 사용한 환원탈지유의 지방 및 고형분 함량 $(10 \%)$ 과 $\mathrm{KM} 32$ 의 낮은 산생성 능력 (Table 5)에 기인된 것으로 판단된다.

\section{요구르트의 저장성}

요구르트를 $4{ }^{\circ} \mathrm{C}$ 에서 10 일간 저장 중 유산균수, $\mathrm{pH}$, 산도 의 변화는 Table 7에서 보는 바와 같다. 혼합 접종구의 경우 전 저장 기간 동안 가장 높은 유산균수를 유지하였으며, 저장 10 일째 $9.28 \log \mathrm{CFU} / \mathrm{mL}$ 이었다. $\mathrm{pH}$ 는 모든 처리구에 서 저장기간 동안 저장 초기와 유사하였으나, $\mathrm{KM} 32$ 접종구 는 점차 증가하여 저장 초기 $\mathrm{pH}$ 4.54에서 저장 10 일째 5.17 로 증가하였다. 이는 저장 중 $\mathrm{KM} 32$ 균주의 단백질 분해능 에 의한 단백질 분해현상에 기인된 것으로 사료된다.

Table 7. Changes in pH, titratable acidity and lactic acid bacteria of yogurt fermented with single and mixed starter during storage for 10 days at $4^{\circ} \mathrm{C}$

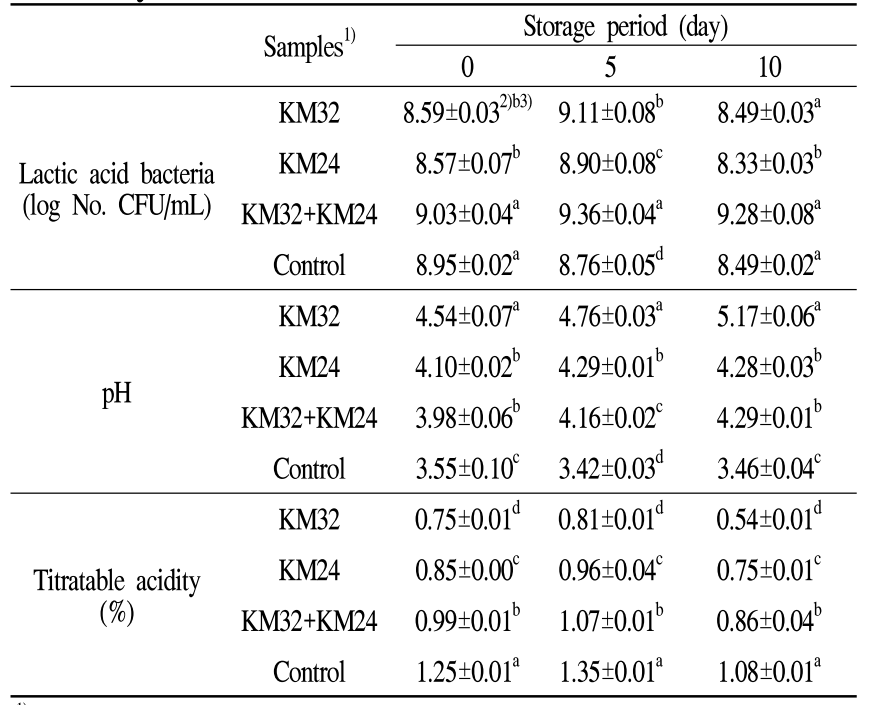

${ }^{1)}$ Control, Lactobacillus. casei, KM32, Pediococcus. pentosaseus, KM24, Lactobacillus. plantarum, KM32+KM23, P. pentosaceus $+L$. plantarum

${ }^{2)}$ Value are means \pm SD of triplicate determinations.

${ }^{3)-d}$ Means within each column with no common superscripts are significantly different $(\mathrm{p}<0.05)$.

산도의 변화는 저장 5 일까지는 다소 증가하다가 그 이후 감소하였다. 혼합 접종구는 대조구에 비해 유산균수는 높 고, 산생성 능력이 낮아 $\mathrm{pH}$ 는 높고, 산도는 낮은 경향을 나타내었다. 유산균의 probiotics 효과를 기대할 수 있는 요구르트의 유산균수는 섭취 전 $10^{8}-10^{9} \mathrm{CFU} / \mathrm{g}$ 이어야 하며, 적어도 $10^{6}-10^{7} \mathrm{CFU} / \mathrm{g}$ 장에 도달하여야 한다(26). 혼합 접종 구는 배양 및 저장기간 동안 $10^{9} \mathrm{CFU} / \mathrm{mL}$ 을 유지하여 섭취 
시 probiotics 효과가 있을 것으로 판단된다.

이상의 결과로 미루어 보아 김치에서 분리한 P. pentosaceus (KM24)와 L plantarum(KM32)는 내산성이 강하고 probiotics 기능이 있으며 발효 및 저장중 높은 수준의 생균수를 유지 하므로 요구르트 제조 시 단독 사용보다는 복합 starter로 사용이 가능할 것으로 판단된다. 상업적으로 활용할 경우 당과 고형분 첨가 등 산 생성을 촉진시키는 방안과 발효온 도 등 적정 발효조건 구명과 품질 개선 등에 관한 광범위한 연구가 선행되어야 할 것으로 사료된다.

\section{요 약}

전통식품에서 요구르트 제조 가능한 유산균을 선발하기 위하여 김치, 식혜 막걸리에서 분리한 유산균 50 균주 중 커드 형성 능력이 있는 16 균주를 선발, L. monocytogenes, $S$. aureus, B. cereus, E. coli, S. entritidis, V. vulnificus에 대한 항균활성과 인공 위액과 담즙액에 대한 내성이 우수한 4 균주를 선발하였다. 4 균주의 환원탈지유에서 배양특성 비교. 항균활성과 인공 위액과 담즙에서의 내성 등을 고려 하여 KM24(구균)와 KM32(간균)을 최종 선발하여 동정한 결과 각각 Pediococcus pentosaceus, Lactobacillus plantarum 로 동정되었다.

요구르트 제조 중 유산균수는 KM24와 KM32균주 혼합 접종구가 가장 높았으며, 배양 48 시간째 $9.66 \log \mathrm{CFU} / \mathrm{mL}$ 을 나타내었다. $\mathrm{pH}$ 는 배양 48 시간째 각각 4.25 (혼합 접종 구), 3.77 (대조구)을 나타내었다. 산도의 변화는 $\mathrm{pH}$ 변화와 유사하여, 배양 72 시간 후 $\mathrm{KM} 32$ 단독 접종구를 제외하고 $0.88-1.24 \%$ 의 범위를 나타내었다. 혼합 접종구와 대조구의 총 폴리페놀함량은 각각 38.45 와 $38.86 \mathrm{\mu g} / \mathrm{mL}$ 이었다. $\mathrm{DPPH}$ 라디칼 소거능은 $\mathrm{KM} 24$ 접종구가 가장 높은 $52.54 \%$ 로, 혼합 접종구(48.57\%)와 대조구(48.22\%)에 비해 항산화 활성이 우수하였다.

혼합 접종구의 경우 $4{ }^{\circ} \mathrm{C}$ 에서 10 일간 저장 중 가장 높은 유산균수를 유지하였으며, 저장 10 일째 $9.28 \log \mathrm{CFU} / \mathrm{mL}$ 이 었다. $\mathrm{pH}$ 는 KM32 접종구를 제외하고 저장기간 동안 저장 초기와 유사하였으며, 산도는 저장 5 일까지는 다소 증가하 다가 그 이후 감소하였다. 혼합 접종구는 대조구에 비해 유산균수는 높았으나 $\mathrm{pH}$ 는 높고, 산도는 낮은 경향을 나타 내었다. 이상의 결과를 미루어 보아 분리균주인 KM24와 $\mathrm{KM} 32$ 은 요구르트 제조 시 복합 starter로 사용이 가능할 것으로 판단되었다.

\section{감사의 글}

이 논문은 대구가톨릭대학교 교내연구비 지원에 의한 것입 니다. 지원에 감사드립니다.

\section{References}

1. Ouwehand AC, Salminen S, Isolauri E (2002) Probiotics: an overview of beneficial effects. Antonie van Leeuwenhoek, 82, 279-289

2. Mohammadi R, Sohrabvandi S, Mortazavian AM (2012) The starter culture characteristics of probiotic microorganisms in fermented milks. Eng Life Sci, 12, 399-409

3. Gilliland SE (1990) Health and nutritional benefits from lactic acid bacteria. FEMS Microbiol Lett, 87, 175-188

4. Jonganurakkun B, Wang Q, Xu SH, Tada Y, Minamida K, Yasokawa D, Sugi M, Hara H, Asano K (2008) Pediococcus pentosaceus NB-17 for probiotic use. J Biosci Bioeng, 106, 69-73

5. Rasic JL, Kurmann JA (1978) Yogurt. In: Scientific Grounds, Technology, Manufacture and Preparations, Techcical Dairy Publishing House, Copenhagen, Denmark, p 369-380

6. Vinderola CG, Bailo N, Reinheimer JA (2000) Survival of probiotic microflora in Argentinian yoghurts during refrigerated storage. Food Res Int, 33, 97-102

7. Park YS, Lee JY, Kim YS, Shin DH (2002) Isolation and characterization of lactic acid bacteria from feces of mewborn baby and from Dongchimi. J Agric Food Chem, 50, 2531-2536

8. Gilliland SE (2003) Probiotics. In: Encyclopedia of Food Science and Nutrition, $2^{\text {nd }}$ ed, Caballero B, Finglas P, Talora F (Editor), Academic Press, Cambridge, MA, USA, p 4792-4798

9. Lee H, Yoon H, Ji Y, Kim H, Park H, Lee J, Shin H, Holzapfel W (2011) Functional properties of Lactobacillus strains isolated from kimchi. Int J Food Microbiol, 145, 155-161

10. Mheen TI, Kwon TW (1984) Effect of temperature and salt concentration on kimchi fermentation. Korean $\mathrm{J}$ Food Sci Technol, 16, 443-450

11. Lee CW, Ko CY, Ha DM (1992) Microfloral changes of the lactic acid bacteria during kimchi fermentation and identification of the isolates. Kor J Appl Microbiol, Biotechnol, 20, 102-109

12. Kim SY, Kim ID, Son JS, Lee SK, Park KJ, Park MS (2011) Biochemical and molecular identification of antibacterial lactic acid bacteria isolated from kimchi. Korean J Food Sci Technol, 43, 446-452

13. Ko KH, Liu W, Lee HH, Yin J, Kim IC (2013) Biological and functional characteristics of lactic acid bacteria in 
different kimchi. J Korean Soc Food Sci Nutr, 42, 89-95

14. Kobayashi Y, Toyama K, Terashima T (1974) Biological characteristics of Lactobacillus. II. Tolerance of the multiple antibiotic resistant strain, Lactobacillus casei PSR 3002, to artificial digestive fluids. Japanese J Microbiol, 29, 691-697

15. Lee SH, No MJ (1997) Viability in artificial gastric and bile juice and antimicrobial activity of some lactic acid bacteria isolated from kimchi. Korean J Appl Microbiol Biotechnol, 6, 617-622

16. Zhang Y, Xu J, Yuan Z, Xu H, Yu Q (2010) Artificial neural network-genetic algorithm based optimization for the immobilization of cellulase on the smart polymer Eudragit L-100. Bioresour Technol, 101, 3153-3158

17. Folin O, Denis W (1912) On phosphotungsticphosphomolybdic compounds as color reagents. J Biol Chem, 12, 239-243

18. Blois MS (1958) Antioxidant determinations by the use of a stable free radical. Nature, 181, 1199-1200

19. Saarela M, Mogensen G, Fonden R, Matto J, MattilaSandholm T (2000) Probiotic bacteria: Safety, functional and technological properties. J Biotechnol, 84, 197-215

20. KFIA (2002) Korean Food Standards Codex. Korea Food Industry Association, Seoul, Korea, p 215
21. Lee BJ, Jinhao C, Park OS, Goh JS, Ahn TS, Park SY (1999) Stability and gastric acid resistance of Lactobacilli and Bifidobacteria in commercial yogurts. Korean $\mathbf{J}$ Microbiol, 35, 89-93

22. Jeong SY, Lee YH, Kang SA, Shin BK, Park SM (2016) Exploration of optimal Lactobacillus plantarum strains for curdling milk for yogurt and evaluation of physicochemical and sensory properties. Korean J Food Sci Technol, 48, 548-554

23. Kim MJ, Lee SH (2017) Quality and fermentative characteristics of yogurt added with hot water extract of Welsh onin root. Korean J Food Preserv, 24, 387-393

24. Salvador A, Fiszman SM (2004) Textural and sensory characteristics of whole and skimmed flavored set-type yogurt during long storage. J Dairy Sci, 87, 4033-4041

25. Lobato-Calleros C, Ramirez-Santiago C, Vernon-Carter EJ, Alvarez-Ramirez J (2014) Impact of native and chemically modified starches addition as fat replacers in the viscoelasticity of reduced-fat stirred yogurt. J Food Eng, 131, 110-115

26. Muniandy P, Shori AB, Baba AS (2017) Comparision of the effect of green, white and black tea on Streptoccous thermophilus and Lactobacillus spp. in yogurt during refrigerated storage. J Assoc Arab Univ Basic Appl Sci, $22,26-30$ 